\section{Psychometric properties of the OHIP-14 and prevalence and severity of oral health impacts in a rural riverine population in Amazonas State, Brazil}

\author{
Avaliação das propriedades psicométricas do OHIP-14 \\ e da prevalência dos impactos da saúde bucal, em \\ população rural ribeirinha no Amazonas, Brasil
}

\author{
1 Faculdade de Odontologia, \\ Universidade Federal do \\ Amazonas, Manaus, Brasil. \\ 2 Escola Nacional de Saúde \\ Pública Sergio Arouca, \\ Fundação Oswaldo Cruz, \\ Rio de Janeiro, Brasil. \\ ${ }^{3}$ Faculdade de Odontologia \\ de Piracicaba, Universidade \\ Estadual de Campinas, \\ Campinas, Brasil. \\ ${ }_{4}^{4}$ Escola Superior de Ciências \\ da Saúde, Universidade \\ do Estado do Amazonas, \\ Manaus, Brasil. \\ ${ }_{5}$ Centro Universitário Nilton \\ Lins, Manaus, Brasil. \\ Correspondence \\ F. Cohen-Carneiro \\ Faculdade de Odontologia, \\ Universidade Federal do \\ Amazonas. \\ Rua Rio Mar 1203, apto. 901, \\ Manaus, AM \\ 69053-120, Brasil. \\ flaviacohen@ufam.edu.br
}

\begin{abstract}
The objectives of this study were: (1) test the psychometric properties of OHIP-14 in a rural population; and (2) compare the oral health impacts in two riverine communities in the Brazilian Amazon that were living at different distances from an urban center. Data were obtained from a cross-sectional study in a consecutive sample ( $n=126)$. The validity was assessed through the association of OHIP with clinical and subjective variables, which showed a more significant association with: pain, caries, need of extraction or endodontic treatment; than with tooth loss, periodontal disease or need of prostheses. The stability and internal consistency were good (ICC = 0.97; Cronbach's $\alpha=0.89$ ). The prevalence of oral impacts was greater in the community far from the urban center [70.3 (59.9-80.7)] than in the community closer to it [44.3 (30.7-57.7)], and in women [66.7 (56.0-77.3)] in comparison with men [49.1 (35.3-62.7)]. The OHIP-14 adapted to rural populations in Amazonas State was valid, reproducible, and consistent. There was high prevalence of impacts, especially for riverine communities that lived far from urban centers.
\end{abstract}

Rural Population; Quality of Life; Oral Health
Flávia Cohen-Carneiro 1

Maria Augusta Bessa Rebelo 1

Reinaldo Souza-Santos 2

Gláucia Maria Bovi Ambrosano 3

Alessandra Valle Salino 4

Danielson Guedes Pontes 4,5

\section{Introduction}

Defining the dental treatment needs of a specific population is an essential step in health policy planning. However, the traditional clinical indicators of oral health, such as the decayed, missing and filled teeth (DMFT) index, the number of missing teeth, or the need for prostheses or endodontic treatment, do not clearly indicate the subjective conditions of individuals with regard to some elements of oral health, such as mastication problems, esthetic limitations and presence of pain 1 .

The socio-dental indicators were developed to assess the subjective impacts on quality of life caused by the oral condition in individuals or populations 2,3. Among these indicators, the Oral Health Impact Profile (OHIP) is an instrument that assesses seven subjective dimensions through structured questions, with answers in a Likert type scale of impact frequency during a certain period of time 4 . The reduced version of this instrument, the OHIP-14, was developed by Slade in 1997, and validated for use in an elderly population in Australia 5, and in an adult population in England 6 and Scotland 7. Furthermore, it was translated and trans-culturally adapted in ten languages $8,9,10,11,12,13,14,15,16,17$, including Portuguese 12. Its validation however, was tested specially on elderly individuals and urban populations, and its use has not been validated for rural populations speaking Latin languages. 
Rural populations, living in isolation from urban centers and with limited access to dental treatment, can perceive the impacts of tooth losses in peculiarly ways. The riverine populations that live along the banks of rivers in the countryside of the Amazonas State, Brazil, were recently characterized for their lack of access to urban centers, low levels of education, a low frequency of using oral health services, an elevated edentulism rate among the young and adult population, and a high prevalence of tooth pain 18,19 . These factors, in addition to cultural and linguistic differences, can reduce the validation of an instrument designed in a different context from the one existent in these populations.

The present study therefore had the following objectives: (1) to test the psychometric properties of the Brazilian version of the OHIP-14 in a rural riverine population, with a low educational level; and (2) to compare the prevalence, severity and extent of the oral health impacts perceived in two rural riverine communities of the Brazilian Amazon, with different degrees of access to oral health services.

\section{Methods}

The data were obtained from a cross-sectional study designed to describe and compare the oral health conditions in two rural riverine communities in the state of Amazonas, each within a different distance from and accesses to the urban center (The Isidoro community is situated $8 \mathrm{~km}$ from the municipal center, and the Lauro Sodré community $65 \mathrm{~km}$ from the urban center). The study was approved by the Research Ethics Committee at the Federal University of Amazonas (process \#130/2004), and all the participants signed the Terms of Informed Consent. The sample was composed of individuals over the age of 18 selected from both communities. Due to the impossibility of performing sample randomization (inexact universe quantification and absence of registration of individuals and addresses), the sample was acquired by means of convenience of access, including the individuals who appeared to the exam location on the previously informed days. The invitation to undergo dental exams was extended to every riverine family, in a personal visit made by the local Community Health Agents, without any expectation of receiving dental treatment.

The study was developed in two steps: a pilot study (January, 2006), and main study (March, 2006). During the pilot study, the logistics for clinical exams were tested and the language used in the original Portuguese questionnaire 12 was adapted by application of the instrument in a group of riverine individuals and discussing it with them ( $\mathrm{n}=10 ; 4$ men and 6 women; mean age: 31.2; mean years of education: 2.89). Small alterations such as replacing the word "stressed" with "nervous", and "relax" with "rest" were made in the final version of the instrument used in the research (Figure 1), because of a lack of understanding of the original terms on the part of the respondents, and adopting their suggestions for changes. Additionally, there were some problems with understanding the options of answers. Hence, standardized explanations were adopted for the frequency scale: never (never in the last six months), rarely (once or twice in the last six months), sometimes (every month or every week in the last six months), usually (almost every day, or twice or more per week in the last six months), always (all the time, or every time that the event in question occurred in the last six months).

During the main study, two types of data collection were performed: clinical exams and interviews. The interviews included the OHIP-14 questionnaire and a structured questionnaire for socio-economic variables. The individuals were clinically examined in accordance with the World Health Organization (WHO) guidelines for epidemiological oral health surveys 20 by one single researcher (F.C.C.) previously trained in a calibration exercise with 20 repeated exams (kappa for crown condition: 0.97; kappa for treatment need: 0.98; kappa for prostheses need: 1.0; kappa for CPI: 0.75), under an artificial light condition (portable head lighting). The dental condition was recorded in accordance with the WHO standardizations for the crown (codes - 0: sound; 1 : decayed; 2: filled, with decay; 3 : filled, no decay; 4: missing, as a result of caries; 5 : missing, any other reason; 6: fissure sealant; 7: bridge abutment, special crown or veneer/implant; 8: unerupted tooth; T: trauma; 9: not recorded), and for the treatment need (codes - 0: none; 1: one surface filling; 2 : two or more surface fillings; 3: crown for any reason; 4: veneer or laminate; 5 : pulp care and restoration; 6: extraction; 7: white spot remineralization; 8: fissure sealant; 9: not recorded) 20 . Thus, the DMFT index was calculated. Additionally, the periodontal condition was assessed by the CPI score (codes - 0: healthy; 1 : bleeding; 2 : calculus; 3 : shallow pockets $4-5 \mathrm{~mm}$; 4 : deep pockets > $6 \mathrm{~mm}$; X: excluded), and the need for prostheses was recorded (codes - 0: no prosthesis needed; 1: need for one-unit prosthesis; 2 : need for multiunit prosthesis; 3 : need for a combination of one- and/or multi-unit prostheses; 4 : need for full prosthesis; 9: not recorded).

The socio-economic questionnaire, as well as the OHIP-14 was administered by another re- 


\section{Nos últimos seis meses, por causa de problemas com seus dentes, sua boca ou dentadura:}

1. Você teve problemas para falar alguma palavra?

2. Você sentiu que o sabor dos alimentos tem piorado?

3. Você sentiu dores em sua boca ou nos seus dentes?

4. Você se sentiu incomodado(a) ao comer algum alimento?

5. Você ficou preocupado(a)?

6. Você se sentiu nervoso(a)?

7. Sua alimentação ficou prejudicada?

8. Você teve que parar suas refeições?

9. Você encontrou dificuldade para descansar?

10. Você ficou com vergonha?

11. Você ficou aborrecido(a) com as pessoas?

12. Você teve dificuldade para fazer suas tarefas diárias?

13. Você sentiu que sua vida, piorou?

14. Você não conseguiu fazer suas tarefas diárias?

searcher (M.A.B.R.) in an interview format, due to the sample population's low educational level. The questionnaire also included the subjective variables: oral health perception (in a single question: "How do you think your oral health is?" 0: did not know/did not inform; 1: very bad; 2: bad; 3: regular; 4: good; 5 : very good), oral pain in the last six months (codes - 0: none; 1 : little pain; 2 : median pain; 3 : lot of pain), and perceived treatment need (codes -0 : needed; 1 : not needed).

\section{$\underline{\text { Statistical analysis }}$}

\section{- OHIP-14 reliability}

In order to test the reliability of the OHIP-14 by means of the Intraclass Correlation Coefficient (ICC), repeated interviews were performed on a group of individuals, through the test-retest method. The internal consistency of the instru- ment and the homogeneity of its seven dimensions were determined using Cronbach's alpha coefficient. Furthermore, the inter-item score correlation and the item-total score correlation were assessed 21 .

\section{- OHIP-14 validity and association with clinical and subjective variables}

The instrument validity was evaluated by verifying the association between the OHIP scores and the designed variables that either objectively or subjectively indicated the oral condition of the riverine populations studied.

The convergent construct validity was assessed by association of the OHIP scores with the following objective clinical parameters: prostheses need (yes, any type of oral prostheses, codes 1 to 4 ; no, not needed, code 0); dental treatment need (yes, presence of at least one 
tooth classified between 1 and 8 in the treatment code; no, all the teeth with codes 0 or 9); need of high impact treatment (yes, presence of at least one tooth classified as 3,5 or 6 in the treatment code; no, absence of teeth with the conditions 3,5 or 6); presence of untreated dental caries (yes, component "D" of the DMFT index differing from zero; no, component “ $D$ ” equal to zero); missing teeth (yes, component "M" of the DMFT index differing from zero; no, component " $\mathrm{M}$ " equal to zero); periodontal condition (according to the CPI index scores). The non-parametric test of Mann-Whitney was used for comparing the OHIP scores with the dichotomic nominal variables described above (after exploratory data analysis using the PROCLAB of the statistic software SAS). For comparing the CPI index and OHIP scores, Spearman's correlation coefficient $\left(r_{s}\right)$ was used.

Further to the convergent construct validity, the association of the OHIP scores with the subjective parameters was also evaluated: presence of pain in the last six months (yes: codes 1, 2 or 3; or no: code 0 ), and perceived need of treatment (yes: code 0; or no: code 1) - Mann-Whitney test.

The concurrent criterion validity was determined by the correlation between the OHIP-14 scores and the single question of self-perceived oral health, using Spearman's correlation coefficient. For the analysis, the answers "did not know/did not inform” were excluded.

\section{- Description of OHIP scores}

The OHIP answers were coded in ordinal values from 0 (never) to 4 (always). After this, the scores were described for prevalence, extent and severity, according to the system established by Slade et al. 22 in 2005:

a) Prevalence: percentage of individuals who answered one or more items with "fairly often" or "very often";

b) Extent: number of items reported as "fairly often" or "very often";

c) Severity: the sum of the ordinal answers that considered the "occasionally" or "hardly ever" experimented impacts, which could range from 0 to 56.

For each community, prevalence, extent and severity were described with $95 \%$ confidence intervals.

The distribution of sex, mean age and years of education in the two communities were compared by the chi-square and Mann-Whitney tests, respectively.

\section{Results}

In order to test the OHIP-14 reliability and validity, 126 individuals were tested (52 in Isidoro and 74 in Lauro Sodré), in which 61 of them answered the exams in duplicate for the ICC. All of the individuals who appeared at the exam location agreed to participate to the research. The sex distribution in the two communities was not statistically different (proportion of women in Isidoro and Lauro Sodré: 59.62\% and 59.46\% respectively, $\mathrm{p}=0.986$ ). The same occurred when evaluating years of education (mean number of years of schooling in Isidoro: $4.58 \pm 3.43$; and in Lauro Sodré: $3.99 \pm 3.80 ; \mathrm{p}=0.15)$. The mean age was higher in Lauro Sodré $(35.70 \pm 12.57)$ than in Isidoro (30.50 \pm 12.61$), \mathrm{p}=0.0091$.

\section{Psychometric properties of OHIP-14 and \\ its association with clinical and subjective variables}

The OHIP-14 stability, determined by the ICC, was excellent $[0.97(0.96-0.98)]$, varying from good to excellent in the 14 items (Table 1).

The internal consistency for the 14 items of the scale was good (0.89; lower limit $95 \%$ CI: 0.86$)$. When evaluated separately, three of the seven dimensions had $\alpha$ values under 0.70 (Table 2). The scale items were moderately correlated among each other, however the item-total correlation

Table 1

Reproducibility of the OHIP-14, measured by Intraclass

Correlation Coefficient (ICC), for each item and

the total score.

\begin{tabular}{lll}
\hline Item & ICC & $95 \% \mathrm{Cl}$ \\
\hline P1 & 0.91 & $0.87-0.95$ \\
P2 & 0.83 & $0.76-0.90$ \\
P3 & 0.86 & $0.80-0.92$ \\
P4 & 0.84 & $0.78-0.90$ \\
P5 & 0.88 & $0.83-0.93$ \\
P6 & 0.87 & $0.82-0.92$ \\
P7 & 0.79 & $0.71-0.87$ \\
P8 & 0.92 & $0.89-0.95$ \\
P9 & 0.79 & $0.70-0.88$ \\
P10 & 0.89 & $0.87-0.91$ \\
P11 & 0.86 & $0.80-0.92$ \\
P12 & 0.89 & $0.84-0.94$ \\
P13 & 0.78 & $0.69-0.87$ \\
P14 & 0.90 & $0.86-0.94$ \\
OHIP-14 & 0.97 & $0.96-0.98$ \\
\end{tabular}


Table 2

Internal consistency of OHIP-14 and of its seven subscales, measured by Cronbach's alpha coefficient.

\begin{tabular}{lc}
\hline Subscales & $\begin{array}{c}\text { Cronbach's } \alpha \text { (lower } \\
\text { limit 95\%Cl) }\end{array}$ \\
\hline Functional limitation & $0.77(0.67)$ \\
Physical pain & $0.66(0.51)$ \\
Psychological discomfort & $0.74(0.64)$ \\
Physical disability & $0.75(0.64)$ \\
Psychological disability & $0.23(0.09)$ \\
Social disability & $0.73(0.62)$ \\
Handicap & $0.57(0.39)$ \\
OHIP-14 & $0.89(0.86)$ \\
\hline
\end{tabular}

was equal to or under 0.20 for questions P9, 11 , 12 and 14 (Table 3).

The OHIP validity was assessed by association of the OHIP scores with the clinical and subjective parameters of each individual. The clinical parameters: need for prostheses, need of treatment, need of high impact treatment, presence of untreated caries and missing teeth; and the subjective parameters: presence of pain in the last six months and self-perceived need of treatment; presented significant association with the OHIP scores $(\mathrm{p}<0.05)$, determining the convergent construct validity (Table 4 ).

The convergent construct validity was also determined by the weak, but significant, positive correlation between the OHIP-14 scores and the CPI index scores: $r_{s}=0.1921(\mathrm{p}=0.0312)-$ Spearman Correlation Coefficient.

The concurrent criterion validity was determined by the negative correlation between the OHIP-14 scores and the single question of oral health self-perception: $r_{s}=-0.4157(\mathrm{p}<0.0001)-$ Spearman Correlation Coefficient.

Prevalence, severity and extent of the OHIP-14 scores in the riverine communities

The prevalence, extent and severity of the negative impacts of oral health on the individuals' quality of life were greater in Lauro Sodré than in Isidoro, although only the prevalence and the severity had shown statistical significance (Table 5).

Comparison between the sexes in the two communities showed a significantly greater prevalence of impacts on women [66.7 (56.0-77.3)] than in men [49.1 (35.3-62.7)]. Although the extent of impacts showed no statistical significance between sexes ( $\mathrm{p}=0.1074$, Mann-Whitney test), the severity was greater in women than in men ( $p=0.0338$, Mann-Whitney test).

\section{Discussion and conclusions}

The psychometric properties of the Brazilian version of OHIP-14, applied to riverine rural populations in the Brazilian Amazon, were acceptable considering the validity obtained, the scale Cronbach's alpha coefficient above the satisfac-

Table 3

Internal consistency of OHIP-14, measured by inter-item and item-scale correlation coefficients.

\begin{tabular}{|c|c|c|c|c|c|c|c|c|c|c|c|c|c|c|c|}
\hline & P1 & P2 & P3 & P4 & P5 & P6 & P7 & P8 & P9 & P10 & P11 & $\mathrm{P} 12$ & P13 & P14 & OHIP-14 \\
\hline P1 & - & 0.77 & 0.13 & 0.56 & 0.54 & 0.51 & 0.63 & 0.45 & 0.35 & 0.55 & 0.30 & 0.36 & 0.49 & 0.12 & 0.27 \\
\hline P2 & - & - & 0.29 & 0.50 & 0.48 & 0.42 & 0.62 & 0.55 & 0.36 & 0.40 & 0.27 & 0.46 & 0.46 & 0.15 & 0.25 \\
\hline P3 & - & - & - & 0.66 & 0.62 & 0.64 & 0.52 & 0.58 & 0.57 & 0.33 & 0.38 & 0.53 & 0.43 & 0.42 & 0.25 \\
\hline P4 & - & - & - & - & 0.77 & 0.67 & 0.84 & 0.65 & 0.55 & 0.57 & 0.54 & 0.59 & 0.58 & 0.36 & 0.36 \\
\hline P5 & - & - & - & - & - & 0.74 & 0.70 & 0.66 & 0.55 & 0.51 & 0.57 & 0.58 & 0.59 & 0.36 & 0.32 \\
\hline P6 & - & - & - & - & - & - & 0.66 & 0.70 & 0.56 & 0.37 & 0.56 & 0.67 & 0.60 & 0.53 & 0.28 \\
\hline P7 & - & - & - & - & - & - & - & 0.75 & 0.57 & 0.43 & 0.59 & 0.62 & 0.59 & 0.41 & 0.33 \\
\hline P8 & - & - & - & - & - & - & - & - & 0.72 & 0.30 & 0.54 & 0.81 & 0.62 & 0.57 & 0.23 \\
\hline P9 & - & - & - & - & - & - & - & - & - & 0.23 & 0.71 & 0.76 & 0.57 & 0.70 & 0.19 \\
\hline P10 & - & - & - & - & - & - & - & - & - & - & 0.12 & 0.20 & 0.49 & 0.17 & 0.26 \\
\hline P11 & - & - & - & - & - & - & - & - & - & - & - & 0.73 & 0.45 & 0.55 & 0.18 \\
\hline P12 & - & - & - & - & - & - & - & - & - & - & - & - & 0.58 & 0.77 & 0.20 \\
\hline P13 & - & - & - & - & - & - & - & - & - & - & - & - & - & 0.57 & 0.23 \\
\hline P14 & - & - & - & - & - & - & - & - & - & - & - & - & - & - & 0.12 \\
\hline
\end{tabular}


Association of the OHIP-14 scores with clinical and subjective variables, to determine the construct validity.

\begin{tabular}{|c|c|c|c|}
\hline \multirow[t]{2}{*}{ Variable } & \multicolumn{2}{|c|}{ OHIP-14 scores } & \multirow{2}{*}{$\begin{array}{c}\mathrm{p} \\
\text { (Mann-Whitney) }\end{array}$} \\
\hline & Mean (SD) & Median & \\
\hline Prosthetics need & & & 0.0266 \\
\hline No $(n=9)$ & $6.11(8.08)$ & 3.00 & \\
\hline Yes $(n=117)$ & $13.26(11.53)$ & 11.00 & \\
\hline Dental treatment need & & & 0.0051 \\
\hline No $(n=17)$ & $6.47(7.71)$ & 4.00 & \\
\hline Yes $(n=109)$ & $13.72(11.65)$ & 11.00 & \\
\hline Need of high impact treatment & & & $<0.0001$ \\
\hline No $(n=49)$ & $7.51(8.48)$ & 4.00 & \\
\hline Yes $(n=77)$ & $16.08(11.88)$ & 14.00 & \\
\hline Presence of untreated dental caries & & & 0.0009 \\
\hline No $(n=19)$ & $5.79(7.55)$ & 3.00 & \\
\hline Yes $(n=107)$ & $13.98(11.60)$ & 12.00 & \\
\hline Missing teeth & & & 0.0444 \\
\hline No $(n=9)$ & $7.22(9.26)$ & 3.00 & \\
\hline Yes $(n=117)$ & $13.17(11.52)$ & 11.00 & \\
\hline Presence of pain in the last six months & & & $<0.0001$ \\
\hline No $(n=66)$ & $7.42(9.35)$ & 4.00 & \\
\hline Yes $(n=56)$ & $18.76(10.90)$ & 16.50 & \\
\hline Perceived need of treatment & & & 0.0049 \\
\hline No $(n=5)$ & $1.80(3.03)$ & 0.00 & \\
\hline Yes $(n=121)$ & $13.20(11.44)$ & 11.00 & \\
\hline
\end{tabular}

tory level (0.70) for group comparisons 23 and the high ICC. As regards some of the scale dimensions, an $\alpha$ coefficient under 0.70 also occurred in the validation of short versions of the OHIP that used this evaluation methodology 10,12 and in the original description of the instrument 4 . This can be justified by the smaller number of items in the short instruments 24 . The moderate correlation among the scale items is desirable, because it reveals colinearity between them. However, items 9 (difficulty to rest), 11 (being a bit irritable), 12 (difficulty to perform your daily activities) and 14 (unable to perform your daily activities) presented a correlation with the total scores of the scale equal to or under 0.20 , which suggests that they did not significantly contribute to the perception of oral health impacts on the lives of these populations. According to Streiner \& Norman 21 an item-total scale correlation under 0.20 suggests the need for removing or rephrasing these items. However, before eliminating the items with low correlation, it is prudent to consider what may have happened. The scale items evaluate more than one dimension of the construct that they represent, therefore weaker correlations between item-total scores can be found. Another plausible explanation for the bad performance of items 9, 11, 12 and 14, would be the composition of the samples. It is strange that in a population with high rates of illnesses - tooth pain prevalence, untreated caries and tooth loss 19 - precisely the items that evaluated the most severe impacts 25 had had less correlation with the total scores of the scale. Perhaps, the riverine populations with little access to and scarcely any dental treatment 18 had learned to live with the oral health impacts on their lives, and even the most severe of these are not considered reasons for psychological or social disability.

The association of the OHIP-14 scores with the clinical and subjective variables obtained for the questionnaire validation, is in accordance with studies of OHIP validation in other populations 12,26,27. However, one additional item of information resulting from the present study was the more significant association with clinical variables defined as being of high impact on the patients. For the interviewed riverine individuals, the presence of pain, untreated caries, teeth requiring extraction or the need for endodontic treatment, were more significant oral conditions for the perception of negative impacts on their 
Prevalence, extent and severity of impacts, in Isidoro and Lauro Sodré communities, Amazonas State, Brazil (estimate $95 \% \mathrm{Cl}$ ).

\begin{tabular}{|c|c|c|c|}
\hline & Isidoro & Lauro Sodré & $\mathrm{p}$ \\
\hline Prevalence (\% of people reporting $1+$ impacts fairly/very often) & $44.3(30.7-57.7)$ & $70.3(59.9-80.7)$ & 0.0034 * \\
\hline Extent (mean number of items reported fairly/very often) & $2.10(1.23-2.96)$ & $2.24(1.66-2.83)$ & 0.1054 ** \\
\hline Severity (mean OHIP-14 scores) & $10.92(7.52-14.32)$ & $14.03(11.53-16.52)$ & $0.0177 * \star$ \\
\hline
\end{tabular}

* Chi-square test;

** Mann Whitney test.

lives than tooth loss, the periodontal condition, or the need for prostheses. This result points out the remarkable contribution of pain and the variables related to it, on the quality of life related to oral health in these populations. A less significant association with tooth losses can be expected in a population in which the consequences of these losses could be minimized by the use of prostheses 28 . However, this was not the case in the studied riverine populations, since the majority of individuals with tooth losses are in need of prostheses 29 .

The mean OHIP found in the riverine populations was higher than the values found in representative samples in Australia (7.4 \pm 0.13$)$ and in England (5.1 \pm 0.11$) 30$, and in Brazilian adolescents $(3.95 \pm 4.88) 31$; and equivalent to the value found in individuals with low frequency of visits to the dentist in Australia 32. Furthermore, the prevalence and extent of the impacts on the riverine individuals were significantly greater when compared with those on populations in Australia and England 22. It is worth pointing out that the convenience sample design used in the present study means that it is not possible to make generalizations. However, obtainment of a random and representative sample of the riverine communities would come up against the difficulties of absence of records and registration of residents, as well as the dispersion of homes along the rivers, which would greatly increase the time and cost of research that included the development of these records in its preliminary stage.

The limited access to oral health services 18 can be a reason for the greater prevalence of the impacts on Lauro Sodré when compared with Isidoro. Sanders et al. 32 described more OHIP impacts on individuals with low frequency of visits to the dentist, when compared with individuals that visited with moderate or high frequency. Another possible explanation is the higher mean age in the population sample of Lauro Sodré. Although the association between age and OHIP scores was not tested in the present study, the supposition of oral problems being more concen- trated in older persons and that these problems would have more impacts on their lives than they would have on the lives of younger persons, has been mentioned in the literature 33 . However one review of the subject pointed out the possibility of interaction or confusion between age and clinical variables such as prostheses use, tooth loss and xerostomia 34

The greater prevalence of impacts on women sustains the hypothesis that women are usually more concerned with their oral health, and perceive either the negative or positive impacts more than men do ${ }^{34}$.

The results of this study showed that the Brazilian version of the OHIP-14 adapted to these riverine rural populations of the Amazon was valid, reproducible and consistent; allowing the definition of oral conditions with greater impact on the quality of life in these populations. However, some items related to psychological and social disability and handicap presented a poor correlation with the total score of the scale. Moreover, a high prevalence was found of negative oral health impacts on the lives of the riverine individuals, especially for the community located further away from the urban center. These findings corroborate the importance of using self-perceiving methods of oral health as a complement to the traditional methods of treatment need, and for planning public policies adapted to the specificities of these populations. 


\section{Resumo}

Os objetivos do trabalho foram: (1) testar as propriedades psicométricas do OHIP-14 em população rural e (2) comparar os impactos da saúde bucal em duas comunidades ribeirinhas amazônicas, com diferentes distâncias do centro urbano. Os dados foram obtidos de uma amostra consecutiva de pacientes $(n=126) \mathrm{em}$ estudo de corte transversal. A validade do instrumento foi testada pela associação do OHIP com variáveis clínicas e subjetivas, sendo mais significativa para as variáveis: dor, cárie, necessidade de extração e de endodontia que para perda dentária, doença periodontal e necessidade de prótese. Estabilidade e consistência interna foram boas $(C C I=0,97 ; \alpha$ Cronbach $=0,89)$. A prevalência de impactos foi maior na comunidade mais distante do centro urbano [70,3 $(59,9-80,7)]$ que na mais próxima [44,3 $(30,7-57,7)]$, e nas mulheres [66,7 (56,0-77,3)] comparadas aos homens [49, 1 (35,362,7)]. O OHIP-14 adaptado às populações rurais da Amazônia foi válido, reproduzível e consistente. A prevalência dos impactos foi alta, especialmente para ribeirinhos que vivem distante dos centros urbanos.

População Rural; Qualidade de Vida; Saúde Bucal

\section{Contributors}

F. Cohen-Carneiro contributed to the study conception, methodological design, data collection and analysis, and writing of the article. M. A. B. Rebelo contributed to the methodological design, data collection and critical review of the manuscript. R. Souza-Santos contributed to the methodological design, data analysis, and critical review of the manuscript. G. M. B. Ambrosano worked on the statistical data analysis, and critical review of the manuscript. A. V. Salino worked on the data collection and critical review of the manuscript. D. G. Pontes worked on the data collection and critical review of the manuscript.

\section{Acknowledgments}

This study was financed by the Funding Agency of the Amazon State (FAPEAM), through the edictal Amazonas' Program to Support Research for Public Policies in Strategic Areas (PPOPE), process \# 1350/05, and through a scholarship fund of the program RH-INTERINSTITUTIONAL-FAPEAM.

\section{References}

1. Sheiham A, Steele JG, Marcenes W, Tsakos G, Finch S, Walls AWG. Prevalence of impacts of dental and oral disorders and their effects on eating among older people; a national survey in Great Britain. Community Dent Oral Epidemiol 2001; 29:195203.

2. Cohen LK, Jago JD. Toward the formulation of sociodental indicators. Int J Health Serv 1976; 6:68198.

3. Locker D. Measuring oral health: a conceptual framework. Community Dent Health 1988; 5:3-18.

4. Slade GD, Spencer AJ. Development and evaluation of the Oral Health Impact Profile. Community Dent Health 1994; 11:3-11.

5. Slade GD. Derivation and validation of a shortform oral health impact profile. Community Dent Oral Epidemiol 1997; 25:284-90.

6. Robinson PG, Gibson B, Khan FA, Birnbaum W. Validity of two oral health-related quality of life measures. Community Dent Oral Epidemiol 2003; 31:90-9.
7. Fernandes MJ, Ruta DA, Ogden GR, Pitts NB, Ogston SA. Assessing oral health-related quality of life in general dental practice in Scotland: validation of the OHIP-14. Community Dent Oral Epidemiol 2006; 34:53-62.

8. Wong MC, Lo EC, McMillan AS. Validation of a Chinese version of the Oral Health Impact Profile (OHIP). Community Dent Oral Epidemiol 2002; 30:423-30.

9. Perera I, Ekanayake L. Prevalence of oral impacts in a Sinhala-speaking older population in urban Sri Lanka. Community Dental Health 2003; 20:23640.

10. Kushnir D, Zusman SP, Robinson PG. Validation of a Hebrew version of the oral health impact profile 14. J Public Health Dent 2004; 64:71-5.

11. Ikebe K, Watkins CA, Ettinger RL, Sajima H, Nokubi T. Application of short-form oral health impact profile on elderly Japanese. Gerodontology 2004; 21:167-76. 
12. Oliveira BH, Nadanovsky P. Psychometric properties of the Brazilian version of the Oral Health Impact Profile - Short form. Community Dent Oral Epidemiol 2005; 33:307-14.

13. Saub R, Locker D, Allison P. Derivation and validation of the short version of the Malaysian Oral Health Impact Profile. Community Dent Oral Epidemiol 2005; 33:378-83.

14. John MT, Miglioretti DL, LeResche L, Koepsell TD, Hujoel P, Micheelis W. German short forms of the Oral Health Impact Profile. Community Dent Oral Epidemiol 2006; 34:277-88.

15. Hägglin C, Berggren U, Hakeberg M, Edvardsson A, Eriksson M. Evaluation of a Swedish version of the OHIP-14 among patients in general and specialist dental care. Swed Dent J 2007; 31:91-101.

16. Bae KH, Kim HD, Jung SH, Park DY, Kim JB, Paik DI, et al. Validation of the Korean version of the oral health impact profile among the Korean elderly. Community Dent Oral Epidemiol 2007; 35:73-9.

17. Rener-Sitar K, Petričević N, Čelebić A, Marion L. Psychometric properties of Croatian and Slovenian short form of Oral Health Impact Profile Questionnaires. Croat Med J 2008; 49:536-44.

18. Cohen-Carneiro F, Souza-Santos R, Pontes DG, Salino AV, Rebelo MAB. Oferta e utilização de serviços de saúde bucal no Amazonas, Brasil: estudo de caso em população ribeirinha do Município de Coari. Cad Saúde Pública 2009; 25:1827-38.

19. Cohen-Carneiro F. Condição de saúde bucal em populações ribeirinhas no Estado do Amazonas: estudo de caso [Doctoral Dissertation]. Rio de Janeiro: Escola Nacional de Saúde Pública Sergio Arouca, Fundação Oswaldo Cruz; 2009.

20. World Health Organization. Oral Health Surveys - basic methods. Geneva: World Health Organization; 1997.

21. Streiner D, Norman G. Health measurement scales. A practical guide to their development and use. Oxford: Oxford University Press; 1995.

22. Slade GD, Nuttall N, Sanders AE, Steele JG, Allen PF, Lahti S. Impacts of oral disorders in the United Kingdom and Australia. Br Dent J 2005; 198:489-93.

23. Bland JM, Altman DG. Statistics notes - Cronbach's alpha. BMJ 1997; 314:572.
24. Awad M, Al-Shamrany M, Locker D, Allen F, Feine J. Effect of reducing the number of items of the Oral Health Impact Profile on responsiveness, validity and reliability in edentulous populations. Community Dent Oral Epidemiol 2008; 36:12-20.

25. Locker D, Allen PF. Developing short-form measures of oral health-related quality of life. J Public Health Dent 2002; 62:13-20.

26. Soe KK, Gelbier S, Robinson PG. Reliability and validity of two oral health related quality of life measures in Myanmar adolescents. Community Dental Health 2004; 21:306-11.

27. Brennan DS, Spencer AJ. Comparison of a generic and a specific measure of oral health related quality of life. Community Dental Health 2005; 22:11-8.

28. Locker D, Matear D, Stephens M, Lawrence H, Fayne B. Comparison of the GOHAI and OHIP-14 as measures of the oral health-related quality of life of the elderly. Community Dent Oral Epidemiol 2001; 29:373-81.

29. Cohen-Carneiro F, Pontes DG, Salino AV, Parente RCO, Souza-Santos R, Rebelo MAB. Prevalência de cárie dental e necessidade de prótese em uma população ribeirinha de Coari-AM: Comunidade Isidoro. Braz Oral Res 2006; 20 Suppl:32.

30. Steele JG, Sanders AE, Slade GD, Allen PF, Lahti S, Nuttall N, et al. How do age and tooth loss affect oral health impacts and quality of life? A study comparing two national samples. Community Dent Oral Epidemiol 2004; 32:107-14.

31. Biazevic MG, Rissotto RR, Michel-Crosato E, Mendes LA, Mendes MOA. Relationship between oral health and its impact on quality of life among adolescents. Braz Oral Res 2008; 22:36-42.

32. Sanders AE, Spencer AJ, Slade GD. Evaluating the role of dental behaviour in oral health inequalities. Community Dent Oral Epidemiol 2006; 34:71-9.

33. Locker D. The burden of oral disorders in a population of older adults. Community Dental Health 1992; 9:109-24.

34. Cohen-Carneiro F, Souza-Santos R, Rebelo MAB. Quality of life related to oral health - contribution from social factors. Ciênc Saúde Coletiva; in press.

Submitted on 22/Sep/2009

Final version resubmitted on $04 / \mathrm{Jan} / 2010$

Approved on 12/Mar/2010 